\title{
Emergency ophthalmology services in the United Kingdom: a snap- shot of service provision
}

\author{
Amy-lee Shirodkar ${ }^{1} \cdot$ Daniel S. Morris ${ }^{2} \cdot$ Damien C. M. Yeo ${ }^{3}{ }^{3}$ M. Kim Lim ${ }^{4} \cdot$ Parul Desai ${ }^{1}$
}

Received: 18 August 2020 / Revised: 27 October 2020 / Accepted: 2 November 2020 / Published online: 16 November 2020

(c) The Royal College of Ophthalmologists 2020

\section{To the Editor:}

UK hospital emergency ophthalmology services (HEOS) are provided locally by individual Trusts with provision influenced by: staffing levels, service level agreements, populations, and geography [1]. This report presents the provision of UK HEOS during 2017-2018 obtained through a Freedom of Information request to all NHS Acute Providers (APs) [2].

Results were received from all APs with a hospital eye service (HES) $(n=127)$ of which $98 \%$ provided a HEOS. The majority of UK APs $(75 \%)$ provided an appointmentbased HEOS, based on telephone triage $(78 \%)$ and available within normal working hours $(69 \%)$. Where available, out-of-hours services are provided directly (77\%), shared through agreement with another local AP $(10 \%)$, or provided wholly by another AP $(13 \%) .27 \%$ of APs provided consultant allocated sessions for HEOS, with the majority (72\%) making provision for follow-up appointments within the HEOS. See Table 1 for national differences.

HES and HEOS services invariably run over-capacity and are faced with challenges of increasing demand and workforce issues [1]. These findings highlight the lack of a direct consultant-led HEOS which would not only ensure clinical leadership, timely service provision and patient safety, but also aid service development, training

\footnotetext{
Amy-lee Shirodkar

amy-lee.shirodkar@nhs.net

Moorfields Eye Hospital, London, UK

2 Cardiff Eye Unit, Wales, UK

3 Alder Hey Children's Hospital, Liverpool, UK

4 Royal Gwent Hospital, Wales, UK
}

and supervision of service staff. A shortage of new consultant posts and numerous vacancies for existing positions, pose a significant risk to the effectiveness and the long-term sustainability of HEOS. A mitigating approach would be the uptake and implementation of the Royal College of Ophthalmologist's common clinical competency framework promoting the use of non-medical staff in HEOS settings [3].

Low-risk ocular conditions may not necessarily need immediate nor hospital attention. Commissioning of urgent community urgent eye care services and HEOS integrated care pathways create a partnership between primary and secondary care, providing an extra layer of triage and management outside the hospital setting which was well demonstrated during the COVID-19 pandemic [4]. Moreover, increased capacity at the sub-specialty level could create direct referral pathways, after triage, of urgent conditions, an avenue for advice and guidance for remote management, as well as reducing the need for follow-up cases within the HEOS.

We recommend that both urgent and emergency ophthalmology pathways are commissioned in a coherent fashion between primary eye care and HEOS. Patients should be directed to NHS111 or primary eye care or GP as their first port of call when faced with an acute eye condition. Onward referral should then be designed depending on local resources but with the aim to get true ocular emergencies rapidly to the eye casualty but keeping as much of the lower-risk conditions out of the hospital settings being treated safely in primary care with access to specialist HEOS advice and guidance to support collaborative co-management and appropriate application of new technology. This would be aligned with national policy to reduce hospital consultations but ensuring patients are seen at the right time by the right person [5].

Monitoring the impact of the pandemic on the availability and accessibility of existing HEOS services should be a priority for the NHS HES, together with evaluation of urgent eye care services commissioned in primary care. 
Table 1 Availability, access and delivery of hospital emergency ophthalmology services in the UK.

\begin{tabular}{|c|c|c|c|c|c|c|c|c|}
\hline Nation & $\begin{array}{l}\text { Total number } \\
\text { of NHS APs } \\
\text { with a HEOS }\end{array}$ & $\begin{array}{l}\text { HES } \\
\text { provided by } \\
\text { another Trust }\end{array}$ & $\begin{array}{l}\text { Walk } \\
\text { in HEOS }\end{array}$ & $\begin{array}{l}\text { Appointment } \\
\text { based HEOS }\end{array}$ & $\begin{array}{l}\text { Combination walk- } \\
\text { in and } \\
\text { appointment HEOS }\end{array}$ & $\begin{array}{l}\text { Availability } \\
\text { a) } 24 \mathrm{~h} \\
\text { b) Long } \mathrm{h}>10 \mathrm{~h} \\
\text { c) Normal working } \\
\text { hours }<9 \mathrm{~h} \\
\text { d) Reduced session } \\
<10 \text { sessions a week }\end{array}$ & $\begin{array}{l}\text { Use of } \\
\text { telephone triage }\end{array}$ & $\begin{array}{l}\text { Consultant } \\
\text { session } \\
\text { in HEOS }\end{array}$ \\
\hline $\begin{array}{l}\text { England } \\
N(\%)\end{array}$ & 108 & $45(42)$ & $18(17)$ & $77(71)$ & $13(12)$ & $\begin{array}{l}\text { a) } 4(4) \\
\text { b) } 19(18) \\
\text { c) } 74(69) \\
\text { d) } 11(10)\end{array}$ & $82(76)$ & $29(27)$ \\
\hline $\begin{array}{l}\text { Scotland } \\
N(\%)\end{array}$ & 11 & $3(27)$ & $0(0)$ & $11(100)$ & $0(0)$ & $\begin{array}{l}\text { a) } 0(0) \\
\text { b) } 0(0) \\
\text { c) } 6(55) \\
\text { d) } 5(45)\end{array}$ & $10(91)$ & $4(36)$ \\
\hline $\begin{array}{l}\text { Wales } \\
N(\%)\end{array}$ & 6 & $1(17)$ & $0(0)$ & $6(100)$ & $0(0)$ & $\begin{array}{l}\text { a) } 0(0) \\
\text { b) } 0(0) \\
\text { c) } 6(100) \\
\text { d) } 0(0)\end{array}$ & $5(83)$ & $0(0)$ \\
\hline $\begin{array}{l}\text { Northern } \\
\text { Ireland } \\
N(\%)\end{array}$ & 2 & $2(100)$ & $1(50)$ & $1(100)$ & $0(0)$ & $\begin{array}{l}\text { a) } 0(0) \\
\text { b) } 0(0) \\
\text { c) } 2(100) \\
\text { d) } 0(0)\end{array}$ & $2(100)$ & $1(50)$ \\
\hline $\begin{array}{l}\text { Total } \\
N(\%)\end{array}$ & 127 & $51(40)$ & $19(15)$ & $95(75)$ & $13(10)$ & $\begin{array}{l}\text { a) } 4(3) \\
\text { b) } 19(15) \\
\text { c) } 88(69) \\
\text { d) } 16(13)\end{array}$ & 99 (78) & $34(27)$ \\
\hline
\end{tabular}

HES hospital eye service, $H E O S$ hospital emergency ophthalmology service, $H B$ health board, $A P$ acute provider.

\section{Compliance with ethical standards}

Conflict of interest The authors declare that they have no conflict of interest.

Publisher's note Springer Nature remains neutral with regard to jurisdictional claims in published maps and institutional affiliations.

\section{References}

1. 'The Way Forward document, The Ophthalmic Services Guidance for Emergency eye care.' https://www.rcophth.ac.uk/wp-content/
uploads/2015/10/RCOphth-The-Way-Forward-Emergency-Eye-Ca re-300117.pdf. Accessed September 2020.

2. www.NHS.uk Accessed August 2017.

3. The Royal College of Ophthalmologists. The Ophthalmic Common Clinical Competency Framework (OCCCF). 2016. https://www. rcophth.ac.uk/professional-resources/new-common-clinicalcompetency-framework-to-standardise-competences-for-ophthalmicnon-medical-healthcare-professionals/. Accessed September 2020.

4. Desai P, Parkins D, Richmond Z. A catalyst for change. Eye (Lond). 2020; Sep 14:1-4.

5. NHS long term plan. 2019. https://www.longtermplan.nhs.uk/. Accessed September 2020. 